\title{
Service Is Power: Exploring Service Quality in Hotel's Business, Yunnan, China
}

\author{
Xiangyu Li \\ ChuXiong Electric Power Supply Bureau of China Southern Power Grid \\ No. 427 of Xiongbao Road, Chuxiong city 675000, Yunnan, China \\ Tel: 86-147-6933-5729 E-mail: axgg2046@hotmail.com \\ Jarinto Krit (Corresponding author) \\ Graduate School of Commerce of Burapha University \\ 169 LonghardBangsean Rd., Chonburi 20131, Thailand \\ Tel: 66-38-394-900 E-mail:krit.dba1@gmail.com
}

Received: February 25, 2012

Accepted: March 26, 2012 Published: May 1, 2012

doi:10.5539/ibr.v5n5p35

URL: http://dx.doi.org/10.5539/ibr.v5n5p35

\begin{abstract}
This study seeks to evaluate the service quality of hotels in the Yunnan province of China and to explore the effects of changes in service quality on customer satisfaction, customer loyalty, and brand image. This study uses both quantitative and qualitative methodologies. A total of 412 questionnaires were returned by study participants and Structural Equation Modelling techniques were used to analyze the data received. Qualitative data collection primarily consisted of in-depth, face-to-face interviews. This study yielded the following results: First, service quality has a positive effect on customer satisfaction, customer loyalty and brand image. Second, customer satisfaction has positive effects on customer loyalty and brand image. Third, customer loyalty has a positive effect on brand image. Finally, by researching the service quality in Yunnan's hotels, this study has provided a reference for hotel service quality management in Yunnan province.
\end{abstract}

Keywords: Service quality, Customer satisfaction, Customer loyalty, Brand image

\section{Introduction}

This research reveals service quality applied to the hotel industry of Yunnan province of China. Service quality is defined as the outcome of a comparison between expectations of a service and what is perceived to have been received.Yunnan's hotel industry has seen increased growth in recent years, mirroring the region's broader economic expansion (Yunnan Statistical Yearbook, YSYB, 2010); however, despite this growth, the industry continues to encounter problems with regard to service quality. Such service failures include: low service quality, poor coordination between departments, and a lack of scientific standards or regulations regarding service quality management. These issues present barriers to the development of Yunnan's hotel industry and therefore require attention.

\subsection{Purpose of Research}

The purpose of this research is to evaluate the quality of service in Yunnan's hotel industry and to investigate the effects of changes in service quality on customer satisfaction, customer loyalty and hotel brand image.

\subsection{Research Hypothesis}

Hypothesis 1: Service quality has a positive effect on customer satisfaction.

Hypothesis 2: Customer satisfaction has a positive effect on customer loyalty.

Hypothesis 3: Service quality has a positive effect on customer loyalty.

Hypothesis 4: Customer loyalty has a positive effect on brand image.

Hypothesis 5: Service quality has a positive effect on brand image.

Hypothesis 6: Customer satisfaction has a positive effect on brand image. 
All above hypothesizes see Figure 1: Framework/ the brief model.

\section{Literature Review}

\subsection{Service Quality}

Parasuraman et al. (1985) defined service quality as the outcome of a comparison between expectations of a service and what is perceived to have been received. According to one marketing study, service quality in hotels can be divided into two categories: functional quality and technical quality (Shiang-Lin et al., 2005). Functional quality represents the service's tangible aspects, while technical quality represents its intangible aspects.

Functional quality's primary focus is on the process of the service. Parasuraman et al. (1988) developed the SERVQUAL model to measure service quality. This model contains the following five primary dimensions: Responsiveness, the willingness to help customers and provide prompt service; Reliability, the ability to perform the promised service dependably and accurately; Assurance, the knowledge and courtesy of employee and their ability to inspire trust and confidence; Tangible, the appearance of physical facilities, equipment, personnel, and communication materials; Empathy: The caring, individualized attention the firm provides its customers. This model suggests that customers measure the degree of service quality when their perception of the service received achieves or exceeds their expectation. The degree of quality can be represented by the following formula: Service Quality = Perceived Service-Expected Service (Parasuraman et al., 1985, 1988).

Technical quality focuses primarily on a hotel's tangible characteristics, such as its location and facilities, to provide a measurement of technical service (Bell, Auh \& Smalley, 2005). It is representing the service as tangible aspects, describes "what is offered" to customer. Technical quality considers the cleanliness of rooms and hallways, the flavour of food, and the collocation of restaurants as components of the hotel's facilities and setting. In this study, the researcher utilized both the SERVQUAL model and an assessment of technical quality to evaluate a hotel's service quality.

\subsection{Customer Satisfaction}

Customer satisfaction is defined as a customer's feelings of pleasure or disappointment resulting from a comparison of the customer's perception of a product's performance (or outcome) to the customer's expectations (Kotler \& Keller, 2009, pp. 164). The literature focuses on the definition of customer satisfaction and contends that there are at least two common determinants of satisfaction: transient satisfaction (transaction-specific) and overall (or cumulative) satisfaction. Transaction-specific satisfaction is a result of the service encounter, but not the service itself. It is formed through an evaluation of the event and the behaviour experienced during the transaction. Overall satisfaction is based on many transient experiences with a service and is the customer's evaluation based on the totality of the product or service.

According to Oliver (1980), satisfaction can also be expressed through the expectation-disconfirmation theory. However, overall satisfaction is a post-decision-making measurement of a specific purchase occasion. Many empirical studies had proved the existence of a positive relationship between service quality and customer satisfaction. In general, service quality always positively influences customer satisfaction (Kara et al., 2005; Olorunniwo \& Hsu, 2006; Qin et al., 2010). As a result, in this study, researcher focus on expectation-disconfirmation theory to develop a measurement to evaluate customer satisfaction in Yunnan hotels (Wei, 2004; Dan, 2007).

\subsection{Customer Loyalty}

Loyalty has been defined as repeat purchase behaviour, which is influenced by a customers' favourable attitude toward a product or service (Kotler \& Keller, 2009, p. 786).

A number of empirical studies have also focused on word-of-mouth (WOM). WOM is an assessment of a product or service, which is communicated between friends or family. According to the studies' authors, WOM can also be seen as a dimension of loyalty (Bloemer et al., 1999; Ganesh, Arnold \& Reynolds, 2000; Yi-Ting \& Dean, 2001; Zeithaml, Berry \& Parasuraman, 1996).

Shiang-Lin et al. (2005) introduced Oliver's four-stage loyalty model, which proposes that the development of customer loyalty consists of the following four stages: cognitive, affective, conation and action. The researcher used re-patronage to measuring the customer loyalty in this study (Gurbuz, 2008).

Harris \& Goode (2004) proposed that in a market environment, trust is a significant factor which influences customer loyalty, therefore enhancing customer trust in a product or service would lead to an increase in loyalty.

Complaint behaviour has been described as a dissatisfaction response to the suppliers of a product or service at the time of final feedback (Bettencourt, 1997; Soderlund, 1998). 
Empirical researchers have found a strong and positive relationship between customer satisfaction and customer loyalty (Oliver, 1980; Williams \& Naumann, 2011; Zeithaml et al., 1996). Furthermore, studies on service quality (Palmer, Beggs \& K-Mcullan, 2000; Bell et al. 2005; Brodie et al., 2009) suggest that high service quality has a positive effect on customer repurchase behaviour. A review of the literature on customer loyalty reveals that WOM, re-patronage, trust and customer complaint behaviour are the four primary components that make up the yardstick of customer loyalty.

\subsection{Brand Image}

According to Keller's (1993) definition, brand image is the "perceptions about a brand reflected as associations existing in the memory of the consumer". This is one of the most widely accepted definitions of brand image in the literature. According to this theory, these associations are developed from a customer's direct experience with a service. Customers make judgements by comparing a company's performance with their prior personal experience, thereby developing new associations about the company. (Martinez \& Pina, 2003).

Many studies have found a positive correlation between customer loyalty and brand image (Zeithaml et al., 1988; Zins, 2001; Selnes, 1993); others have proved that service quality has a positive effect on brand image (Kayaman \& Arasli, 2007; Balmer, 2001; Brodie et al., 2009). Finally, empirical studies have also indicated that customer satisfaction has a positive effect on a firm's brand image (Brodie et al., 2009; Gi-Du \& James, 2004; Torres \& Tribo, 2010). In this study, the researcher relied on Brodie's model (2009) and referred to other successful research (Kayaman \& Arasli, 2007) to identify brand image as the final of the four variables.

\section{Research Methodology}

This study adopted both quantitative and qualitative methods. Quantitative data was collected via questionnaires sent to study participants. The data collected was then analyzed using Structural Equation Modelling (SEM) technique. Qualitative research was primarily conducted through in-depth face-to-face customer interviews.

\subsection{Sample}

Sampling for quantitative data: This study was directed at customers of 3-star hotels in Yunnan province. Sampling was carried out in two stages: Stage 1 was to identify target hotels using a judgemental sampling method. Researcher chose Yunnan's top four cities by tourism revenues (Kunming, Dali, Lijiang, and Jinghong) as shown in Tourism Revenue of Yunnan Province 2009 (Table 1). Using a random sampling method, two 3-star hotels were selected from each of the four cities. Stage 2 was to collect information from customers of the selected hotels. Researcher contacted managerial personnel from each of the 8 hotels and asked for their assistance with questionnaire administration. This survey was conducted using a simple random sampling.

The sampling for qualitative data was obtained via face-to-face interviews. Data received from interviews is regarded as supplementary to the study's qualitative data. The researcher attempted to interview 10 to 15 customers who had completed questionnaires at one of the target hotels. The questionnaire consisted of 6 questions (shown in 4.2 of Result of Research) and took between 30 to 45 minutes per person.

Interviews and questionnaires were anonymous and returned directly to us, so as not to be biased by hotel personnel.

\subsection{Measurement and Reliability}

The four variables of this study were: service quality, customer satisfaction, customer loyalty and brand image. Each variable was separated into diverse dimensions which consisted of appropriate items. Because most of the original questionnaires used to evaluate these variables were developed in western countries, they were professionally translated into Chinese to account for differences in Chinese culture. In this study, a total of 52 items were measured using a 5-point Likert-type scale where $1=$ strongly disagree (extremely unlikely), 3 = neither disagree nor agree, and $5=$ strongly agree (extremely likely).

A pilot test (30 samples) was administrated to test Cronbach Alpha reliability before the actual collection of data.

Both items of measurement and result of reliability are shown in the Table 2.

\section{Resultof Research}

\subsection{Quantitative}

In this study, the researcher sent 800 questionnaires in total, and 412 valid copies were returned (see Table 3 ). According to the data from questionnaires, researcher built the SEM technique. Based on Schumacker \& Lomax (2004)'s theory, researcher listed Table 4 that shown Goodness of fit test of SEM, meanwhile. Table 4 also revealsa good fit of this study which as follows: RMSEA is 0.02 , GFI is 0.97 , RMR is 0.01 , NFI is 1.00 , NNFI is 1.00 and CFI is 1.00. Moreover, Figure 2 describes the research model is accepted model. The Chi-square equal to 148.78, the 
degree of freedom equal to 129 , thus the Chi-squal / $\mathrm{df}=1.15$ was less than 2 , p-value equal to 0.11 was more than 0.05 , the RMSEA equal to 0.019 was less than the 0.05 . All of those results are achieved the recommended value, thus the model's was passed requirements.

According to Figure 2, the service quality, tangible, reliability, responsiveness, assurance, empathy and technique quality are significant of t-value $(23.99,23.01,23.74,24.16,25.85$ and 25.16), meanwhile, all these service qualities were indicated as important factors to customer satisfaction, customer loyalty, and the negative indications were about brand image. All of the customers satisfaction (CS1 - CS4) are significant of t-value $\left(^{*}, 26.92,27.96\right.$ and 25.61), these all customer satisfaction were indicated important factors to customer loyalty and brand image. The customer loyalty, word-of-mouth, re-patronage, trust and complaining are significant of t-value $(*, 33.10,35.04$ and 28.89), all of the customer loyalty were indicated important factors to brand image. The entire brand image (BI1 BI5) are significant of t-value (*, 26.34, 24.35, 24.72, 22.26, and 23.84). Thus, customer satisfaction, customer loyalty and brand image were found good predictors with service quality $\mathrm{R}^{2}(0.82,0.95$ and 0.98$)$.

The result of the SEM as following, and the brief figure was showed in Figure 3. According to Figure 3, it shows the results of the hypothesis of this research.

The service quality has the positive effect to customer satisfaction $\left(0.91^{* * *}\right)$ at the significant level t-value of 20.37 , the H1 was significant.

The customer satisfaction has the positive effect to customer loyalty $\left(0.30^{* * *}\right)$ at the significant level t-value of 6.49 , the $\mathrm{H} 2$ was significant.

The service quality has the positive effect to customer loyalty $\left(0.69^{* * *}\right)$ at the significant level t-value of 13.14 , the H3 was significant.

The customer loyalty has the positive effect to brand image $\left(0.75^{* * *}\right)$ at the significant level $\mathrm{t}$-value of 5.57 , the $\mathrm{H} 4$ was significant,

The service quality has the negative effect to brand image (-0.18) at the significant level t-value of -1.66 , the H5 was rejected.

The customer satisfaction has the positive effect to brand image $\left(0.43^{* * *}\right)$ at the t-value of 6.63 , the H6 was significant.

Table 5 shows path analysis between exogenous and endogenous latent variables. Within this table, the "SQ" was the service quality, the "CS" was customer satisfaction, "CL" was the customer loyalty and the "BI" was the brand image. The service quality has direct effect to customer satisfaction $\left(0.91^{* * *}\right)$ at the significant level of 0.01 . The service quality direct effect to customer loyalty $\left(0.70^{* * *}\right)$ at the significant level of 0.01 , and the indirect effect was 0.27 . The customer satisfaction has direct effect to the customer loyalty $\left(0.30^{* * *}\right)$ at the significant level of 0.01 . The customer satisfaction direct effect brand image $\left(0.44^{* * *}\right)$ at the significant level of 0.01 , and the indirect effect was 0.22 . The customer loyalty has direct effect to brand image $\left(0.75^{* * *}\right)$ at the significant level of 0.01 .

\subsection{Qualitative}

The qualitative research through face to face interview toget data, there were totally 6 objectives.Finally, there were 8 volunteers accepted the interview, the 6 objectivesare as the follows, each answer was integrated the 8 volunteers' primary idea, made the conclusion answers.

1. To know customers' perception of the target hotels, let them give an overall and personal appraisal of the hotel which they have been living in. Meanwhile, the appraisal was about the service components of the hotel.

Conclusion: According the answers, customers were satisfied with the hotel. There were a few customers (or guests) who felt that the hotel where they stayed was satisfactory, primarily due to the good attitude of the staff and good facilities also these hotels understand the customers (guests) needs and can give them what they want.

2. To understand the customers degree of satisfaction at the hotels, and gain a greater knowledge of their expectations in order to satisfy them. This will also help to indicate which service areas need to be improved.

Conclusion: The key point for the hotels that want high levels of customer satisfaction is the volunteers primary focus on level of service quality. If hotel could give higher level service to customers then the customer will be satisfied.

3. To understand a customer's loyalty to a particular hotel (will they choose this hotel again when they come to this city the next time), and try to discover what are the key points that attract them to the hotel.

Conclusion: According to the answers, Most customers' personal experience points to the following factors when deciding whether to return or not, service quality was the most important point to affect their decision to return with 
some interviewees describing service as the soul of the hotel. The other factor is the environment both internal and external and customers are mostly concerned with noise levels. People also like convenient traffic connections and location is important, closeness to supermarkets and entertainment being of primary importance. The last factor is sanitation levels, customers like the hotel to have a clean environment.

4. To understand the hotels brand image in the customers mind, and gain in-depth knowledge of how a hotel wants to be remembered and which factors will influence the customers return business.

Conclusion: According to the answers, the primary factors that determine the customers understanding of the brand image are as follows- first it must have a good standard of service. Also the hotel needs some kind of special service to give guests different experiences. The second point is the hotel needs to have beautiful decorations, if they have that it will give the guests a sense of security, and they will think it is clean and has good sanitation. Thirdly the hotel needs to have a good environment, they hope that the hotels entertainment facilities will not be too noisy and disturb them.

5. To know whether the customer will change (decrease or increase) their level of satisfaction, loyalty and brand image to the hotel if the hotel changed their service quality.

Conclusion: According to the answers, all the interviewees agree that if the quality of service was increased their level of satisfaction would do so also. Also their loyalty would increase and they would have a clear understanding of the brand image of the hotel.

6. To know if the hotel increased their service quality, will the customer's level of satisfaction be influenced first, and will it continue to influence their loyalty or will their loyalty be the first to be influenced, and their satisfaction second.

Conclusion: According to volunteers' answers, seven people agree that if the quality of service was improved then the first thing to be influenced would be their satisfaction and secondly their loyalty, most of them agreed that satisfaction is like a benchmark to evaluate their loyalty to a particular hotel. There was one person who stated that their loyalty would be the first thing to be influenced followed by customer satisfaction. Through the interview, to know the relationships of research in more details, and knows the truth of what the customer's thinking.

Finally, according to the interview's answers, all of the six hypothesizes of this study were significant in qualitative ways.

\subsection{Findings}

According to the results, there were findings of this study: Firstly, customers always agree that if a hotel's service quality changes, these changes may include both positive and negative aspects. Their satisfaction, loyalty and people's perceptions of the brand image of a hotel are connected to service quality changes either positive or negative. Customers consider service quality to be the no.1 aspect that would influence their satisfaction, loyalty and their perceptions of the brand image of the hotel. Secondly, if customers are deciding which hotel to return to, they would prefer to choose a hotel with a high quality of service, good environment and convenient traffic connections. If the hotel can provide the customers with more surprises their satisfaction will increase and they will return. All of these issues are connected to service quality. Thirdly, concerning the brand image, customers agree that their degree of loyalty would influence their memory and image of the hotel. It is dependent on the level of service quality, and their satisfaction influences their perception of the brand image. Fourth, this research has found that the service quality, customer satisfaction, customer loyalty and the brand image of the hotel interact together. There was not one single activity all of the activities are integrated together.

\section{Conclusion}

This study has proved the six relationships and the conclusion were as following paragraphs:

Hypothesis 1: Service quality has a positive effect on customer satisfaction. The results of the quantitative research showed that service quality had a positive effect on customer satisfaction $\left(0.91^{* * *}\right)$ at a significant level of t-value 20.36, the $\mathrm{H} 1$ are significant. The results of the qualitative research showed all the interviewees in agreement that if the hotel increased their service quality then their degree of satisfaction would also increase accordingly. These results maintained congruence with empirical studies (Kara et al., 2005; Olorunniwo \& Hsu, 2006; Qin et al., 2010) showing that customer satisfaction was positively affected by an increase in service quality.

Hypothesis 2: Customer satisfaction has a positive effect on customer loyalty. The results of the quantitative research showed that customer satisfaction had a positive effect on customer loyalty $\left(0.31^{* * *}\right)$ at a significant level of t-value 6.66 and the $\mathrm{H} 2$ are significant. The results from the qualitative research showed that all the interviewees were in agreement that their loyalty came from increasing satisfaction. Empirical studies have proven this 
relationship between customer satisfaction and loyalty. The research by Oliver (1980), Williams \& Naumann (2011), and Zeithaml et al. (1996) has found that there was a strong positive relationship between customer satisfaction and their repurchase behaviors.

Hypothesis 3: Service quality has a positive effect on customer loyalty. The result of quantitative research showed that service quality had a positive effect on customer loyalty $\left(0.69^{* * *}\right)$ at a significant level of t-value of 13.11 , and the H3 are significant. The results from all the qualitative research showed all interviewees in agreement that customer loyalty was positively affected by service quality, the interviewees generally agreed that if they were to return, the first factor to take into consideration was the level of service. This result maintained congruence with other empirical studies (Park et al., 2008; Palmer, Beggs \& K-Mcullan, 2000; Bell et al., 2005; Brodie et al., 2009; Webster \& Sundaram, 1998) which showed that service quality has a positive effect on customer loyalty.

Hypothesis 4: Customer loyalty has a positive effect on brand image. The results of the quantitative, research showed customer loyalty was positively affected by brand image $\left(0.75^{* * *}\right)$ at the significant level of t-value 5.80 and the $\mathrm{H} 4$ are significant. All of the qualitative, research shows interviewees in agreement that when their customer loyalty increases so does their perception of the brand image. This result maintains congruence with Selnes (1993), Zeithaml et al. (1988) and Zins (2001) who show that customers are positively affected by brand image.

Hypothesis 5: The service quality has a positive effect on brand image. In this study the results of the quantitative, research show that service quality has a negative effect on brand image $(-0.19)$ at the significant level of t-value -1.87 , and the $\mathrm{H} 5$ was rejected. All of the qualitative research shows interviewees in agreement that service quality has a positive effect on brand image. Thus, in this factor line only the qualitative research maintained congruence with empirical studies (Balmer, 2001; Brodie et al., 2009; Yoo, Donthu \& Sungho, 2000) that the service quality has a positive effect to brand image.

Hypothesis 6: Customer satisfaction has a positive effect on brand image. The results from the quantitative, research showed that if customers were satisfied it would have a positive effect on brand image $\left(0.43^{* * *}\right)$ at the significant level of t-value 6.61 and the H6 was significant. The qualitative, research shows that customer satisfaction has a positive effect on brand image. Thus the results are the same as empirical studies by (Kang \& James, 2004; Roderick et al., 2009; Torres \& Tribo, 2010) showing that customer satisfaction has a positive effect on brand image.

\section{Implementation of Study}

\subsection{Solving Current Problem}

\subsubsection{Service Quality}

According to the results of this research, the suggestions of service quality given to hotels were able to be separated into two parts. First part is the facilities, gyms should be built, and if space allows it hotels should build small fitness centers. Make the meeting rooms function perfectly. Fully equip the internet bar so as to be able to offer guests that service, or alternatively the hotel should purchase some laptops which could be rented to guests. Appliances in the rooms should be in good working order, make sure the guests are comfortable, such as carpets and wall paper should be changed on a regular basis to increase the aesthetics, loading wireless for internet, hotels should offer a free and high speed internet connection. The quality of the bedding should be increased to enable guests to sleep comfortably. Rooms should be equipped with electric hair dryers and scales etc. to make the guests stay more convenient. And the second part is service should be optimized in the following areas. Increase the standards, display courtesy to guests, (more details) customize their service to be faster in order to satisfy the different needs of guests. Enhance employee's service skills, and increase the overall level of service and through training make the standards perfect. Staff should react and deal with guests requests promptly in order to satisfy their different needs.

\subsubsection{Customer Satisfaction}

According to the results of this study, the suggestions on customer satisfaction comprises of the following two components: Firstly, customer satisfaction is an objective, hotels are supposed to understand that what are customers' demands, these demands change according to their level of satisfaction. Satisfaction program should be integrated into the hotels overall operating procedures. Service should be well designed and should offer different types according to customers' needs, establishing a high level of service will increase customers' loyalty to the hotel. Secondly, only got the satisfaction is not enough. Hotels that gain revenue from satisfied customers are few, they are an unstable group and tend to abandon a hotel which has a normal level of service. Thus if only satisfaction is achieved they may not be loyal to the hotel, so merely being content is not enough.

\subsubsection{Customer Loyalty}

The purpose of loyalty is to attract customers to return to the hotel. Through analysis researcher find the following results: Firstly, customer loyalty was influenced by service quality, most customers regarded service quality as the 
no.1 influence on their loyalty. Thus hotels should increase customer loyalty by first completing their service building. There were limited effects with the hotels planning to attract customer loyalty. If a hotel could keep their customer as well as cultivate their loyalty, it would have to increase its level of service, expand their service programs, and raise the customer perception. Secondly, the hotel needs to keep innovating and adding more programs, do more investigation into customers' needs, and be able to deal with customers' new ideas. According to customers' needs design a program to add-value, and create more surprises for customers.

\subsubsection{Brand Image}

According to the results of this study, firstly, the hotel should enhance their service quality. Secondly, the hotel should create the add-value points of service, and add more surprises to customers. Hotels should establish a distinctive clear image, engage in more communication with customers, find out customers' needs and achieve them, and enhance the customer's impression of the hotel's brand image. After that, it should build up long-term relationships with customers, more focus on the differentiation strategy of a hotel's image, to distinguish it from other hotels. Thirdly, the hotels should establish a positive and active company image, using multiple media channels to improve their brand image and their reputation.

\subsection{Long-termbenefit Operating Strategy}

\subsubsection{Employee Training}

Service occurs between guests and the hotel's reception and attendant personnel, these are personnel who work on the "front-line". Their performance affects customers' perceptions and they are the ones who most influence customers' evaluation of a hotel's service. Therefore, it's obvious that training employees well is essential. However, training without objectives doesn't yield results. Hotels must institute targeted training programmes to employees in the following areas.

Promotion service training: A sophisticated employee is not only professional in appearance, courteous, amicable and professionally skilled, but also must be good at promotion. For instance, front-desk receptionists should be able to provide information to guests about local tourist spots and historic sites; porters should be able to introduce the hotel's service facilities and promote the hotel's products to guest when they are leading guests to their rooms or helping to carry luggage; restaurant staff should be positive and enthusiastic and help guests choose dishes that suit their individual tastes. These activities not only work as promotions, but also provide information to customers so they can become familiar with the hotel's facilities and services more quickly.

Value-added service training: Guests should perceive a hotel as a home, full of warmth, comfort and human kindness. Therefore, hotels employees should cultivate an environment in which guests are treated as family, not just as the objects of service. Furthermore, value-added service includes foresight, so employees should be trained to know their guests' needs before they ask.

Facility service: Managers need to pay attention the hotel's internal facilities, making sure that if a guest asks about the hotel's products or services, they can introduce them accurately, since sometimes managers fill-in when other "front-line" personnel are not available. Managers should be familiar with the hotel's information booklet, menus placed in rooms or restaurants, and convenience items offered free-of-charge, such as lighters, napkins, and small gifts.

Language service: In speaking with guests and in the hotel's literature, language should be: Intelligible, expressions should be accurate, so guests don't need to ask twice; Upfront, hotel staff should enquire as to the customers' needs; Respectful, hotel staff should use honorific language when speaking with guests; Restricted, employees should limit conversation with guests to subjects necessary to perform their jobs; Reliable, employees must put their words into deeds.

\subsubsection{Organizational Changing}

Hotels have to build organizations to guarantee proper implementation of the hotel's services, therefore in some cases, organizational change will be necessary. Hotels should build a "customer-oriented" organization style. This model emphasizes teamwork and the transverse interaction between departments and individuals or between the hotel's internal and external working grid. Research by Jing and Baijus (2009) provides a good reference for improving a hotel's managerial function and includes the following suggestions:

Decrease the hierarchical nature of the organization: Currently, many Chinese hotels utilize a hierarchical-style organizational structure, which has the following five levels from top to bottom: general manager, departmental manager, supervisor, captain, staff. In an organization of this type, information moves level by level from bottom to top, as a result, information moves slowly and is often lost. This model engenders low efficiency. Hotels should 
remove a layer of middle management, using a model similar to the following: general manager, front office manager, reception supervisor, staff. This model increases speed of information transfer and increases management efficiency, allowing higher leaders to receive customer feedback more quickly.

Establish an inverted pyramid management model (see Figure 4): In Figure 4, "TM" represents top management and "MM" represents middle management. On the left is a traditional organizational structure. Under this model, managers rarely understand the real situation found on the front-line. On the right is an inverted pyramid model. Under this model, staffs are located at the top and managers supply resources to them. Staffs receive security from managers, improving their working efficiency. Furthermore, if a customer's needs are met the first time, their satisfaction and loyalty will increase, resulting in an improved brand image.

\section{Limitation of Study}

1. Service quality has been developing for a long time, and it is a complete theory system right now. But this study only picks up a transverse section from the whole theory system, no more depth research for understanding the whole service history. In reference of this study, practical information and academic theories are still not enough.

2. Regarding the sampling, although more than 400 questionnaires were collected and 8 volunteers were interviewed. The samples only represented a part of the population of all of the guests, because of limited sources and personal ability. This research only focused on 4 cities in Yunnan as well as other 3 star hotelswhich were the target for collecting, thus the study lacks universalism and is not large enough to cover the whole hotel industry.

3. This research study was conducted using information from relevant literature, but only utilized a particular form of research. Although the empirical results of this study found there were significant effects between service quality, customer satisfaction, customer loyalty and brand image, in reality the relationships among those variables were more complicated than could be fully comprehended due to the scope of this study. Thus further research needs to be conducted in this field for it to be fully understood.

4. This study is a static type of research, but service quality, customer satisfaction, customer loyalty and the brand image, all of these are in a dynamic process of developing. As time goes on, customers' needs will change, thus their standardsof service quality will change, and then everything will change. Therefore, this research needs developing and changing, the best research is conducted under dynamic situations.

\section{Suggestion for Future Research}

1. Pay more attention to research progresses on hotel management, continue to complement and consummate the theory. Simultaneously, make more research focusing on measurements and variables, such as the degree of effects between tangible elements and customer satisfaction, reliability and customer satisfaction, empathy and customer satisfaction and the like. Pay more attention to details.

2. To prove the universality of this study, the research of this study would choose more different industries and different markets in the future, to expand the scale of sampling.

3. This study only chooses service quality, customer satisfaction, customer loyalty and brand image as the factors to research. There are other factors that would influence the relationships of the four variables, such as customer value, customer awareness, market competition, customer consumption, sense of safety and the like. Thus in the future it would be worth considering adding those factors in the current model, to make the model more perfect.

4. Research conducted into hotels would take up a large amount of time, human resources and material resources. In the futureit may be possible to adopt the long-term tracking survey, operating dynamic research to get more accurate data. Continue to research in depth those relationships among service quality, customer satisfaction, customer loyalty and the brand image.

\section{References}

Bell, S. J., Auh, S., \& Smalley, K. (2005). Customer relationship dynamics: service quality and customer loyalty in the context of varying levels of customer expertise and switching costs. Journal of the Academy of Marketing Science, 33(2), 169-183. http://dx.doi.org/10.1177/0092070304269111

Bettencourt, L. A. (1997). Customer voluntary performance: customers as partners in service delivery. Journal of Retailing, 73(3), 383-403. http://dx.doi.org/10.1016/S0022-4359(97)90024-5

Bigné, J., Sanchez, M., \& Sanchez, J. (2001). Tourism image, evaluation variables and after purchase behavior: $\begin{array}{lllll}\text { interrelationship. Journal of Tourism } & \text { Management, } & \text { 22(6), }\end{array}$ http://dx.doi.org/10.1016/S0261-5177(01)00035-8 
Bloemer, J., Ruyter, K., \& Wetzels, M. (1999). Linking perceived service quality and service loyalty: a multi-dimensional perspective. European Journal of Marketing, 33(11/12), 1082-1106. http://dx.doi.org/10.1108/03090569910292285

Brady, K. M., \& Cronin. (2001). Some new thoughts on conceptualizing perceived service quality: a hierarchical approach. Journal of Marketing, 65(6), 34-49. http://dx.doi.org/10.1509/jmkg.65.3.34.18334

Brodie, R. J., Whittome, J. R. M., \& Brush, G. J. (2009). Investigating the service brand: A customer value perspective. Journal of Business Research, 62, 345-355. http://dx.doi.org/10.1016/j.jbusres.2008.06.008

Chen, L. (2010). 2010 Yunnan Statistical Yearbook: Statistical Bureau of Yunnan Province \& Survey Office of the National Bureau of Statistics in Yunnan. China: Electronic Publications Press.

Chengwei, G. (2010). The empirical study on the relationships among hotels service quality, customer value and customer satisfaction: case study of individual 3-star hotels in TaianCity. (Master's thesis). Department of Graduate School of Commerce, ShanDong University.

Dan, S. (2007). A research that strategies of function improving and changing of World Expo Garden Hotel. (Master's thesis). Department of Business Administration, League of Kunming University of Science and Technology.

Eugene, W. A., Fornell. C., \& Lehmann, R. L. (1994). Customer satisfaction, market share, and profitability: findings from Sweden. Journal of Marketing, 58, 53-66. http://dx.doi.org/10.2307/1252310

Gi-Du, K., \& James, J. (2004). Service quality dimensions: an examination of Grönroos's service quality model. Managing Service Quality, 14(4), 266-277. http://dx.doi.org/10.1108/09604520410546806

Gronroos, C. (1998). Marketing services: the case of a missing product. Journal of business \& Industrial Marketing, 13(4/5), 322-338. http://dx.doi.org/10.1108/08858629810226645

Gurbuz, E. (2008). Retail store branding in Turkey: its effect on perceived quality, satisfaction and loyalty. EuroMed Journal of Business, 3(3), 286-304. http://dx.doi.org/10.1108/14502190810906446

Harris, L. C., \& Goode, M. M. H. (2004). The four levels of loyalty and the pivotal role of trust: a study of online service dynamics. Journal of Retailing, 80, 139-158. http://dx.doi.org/10.1016/j.jretai.2004.04.002

Jing, T., \& Baiju, Z. (2009). Study on the strategies of internal service recovery in hospitality. Journal of Harb University of Commerce, (5), 113-116. http://www.cqvip.com/qk/97213A/200905/ (May 10, 2009)

Kara, A., Lonial, S., Tarim, M., \& Zaim, S. (2005). A paradox of service quality in Turkey The seemingly contradictory relative importance of tangible and intangible determinants of service quality. European Business Review, 17(1), 5-20. http://dx.doi.org/10.1108/09555340510576230

Kayaman, R., \& Arasli, H. (2007). Customer based brand equity: evidence from the hotel industry. Journal of Managing Service Quality, 17(1), 92-109. http://dx.doi.org/10.1108/09604520710720692

Keller, K. L. (1993). Conceptualizing, measuring and managing customer-based brand equity. Journal of Marketing, 57(1), 1-22. http://dx.doi.org/10.2307/1252054

Keller, K. L., \& Lehamn, D. R. (2006). Brands and branding: Research finding and future priorities. Journal of Marketing Science, 25(6), 740-759. http://dx.doi.org/10.1287/mksc.1050.0153

Kotler, \& Keller. (2009). Marketing Management (13th ed.). New Jersey: Pearson Education International.

Loureiro, S. M. C., \& Kastenholz, E. (2010). Corporate reputation, satisfaction, delight, and loyalty towards rural lodging units in Portugal. International Journal of Hospitality Management, 30(3), 575-583. http://dx.doi.org/10.1016/j.ijhm.2010.10.007

Martinez, E., \& Pina. J. (2003). The negative impact of brand extensions on parent brand image. Journal of product \& brand management, 12(7), 432-448. http://dx.doi.org/10.1108/10610420310506001

Moorman, C., Zaltman, G., \& Deshpande, R. (1992). Relationships between providers and users of market research: the dynamics of trust within and between organizations. Journal of Marketing Research, 29(3), 314-329. http://dx.doi.org/10.2307/3172742

Ng, S., David, M. E., \& Dagger, T. S. (2011). Generating positive word-of-mouth in the service experience. Journal of Managing Service Quality, 21(2), 133-151. http://dx.doi.org/10.1108/09604521111113438

Oliver, R. L. (1980). A cognitive model of the antecedents and consequences of satisfaction decisions. Journal of Marketing Research, 17(4), 460-469. http://dx.doi.org/10.2307/3150499 
Olorunniwo, F., \& Hsu, M. K. (2006). A typology analysis of service quality, customer satisfaction and behavioral intentions in mass services. Managing Service Quality, 16(2), 106-123. http://dx.doi.org/10.1108/09604520610650600

Palmer, A., Beggs, R., \& Caroline, K-M. (2000). Equity and repurchase intention following service failure. Journal of Services Marketing, 6(6), 513-528. http://dx.doi.org/10.1108/08876040010347624

Parasuraman, A., Zeithaml, V. A., \& Berry, L. L. (1985). A conceptual model of service quality and its implications for future research. Journal of Marketing, 49(4), 41-50. http://dx.doi.org/10.2307/1251430

Parasuraman, A., Zeithaml, V. A., \& Berry, L. L. (1988). SERVQUAL: A multiple-item scale for measuring consumer perceptions of service quality. Journal of Retailing, 64(1), 12-40. http://dx.doi.org/10.1016/S0148-2963(99)00084-3

Parasuraman, A., Zeithaml, V. A., \& Malhotra, A. (2005). ES-QUAL:Amultiple-item scale for assessing electronic service quality. Journal Service Research, 7(3), 213-233. http://dx.doi.org/10.1177/1094670504271156

Qin, H., Prybutok, V. R., \& Zhao, Q. (2010). Perceived service quality in fast-food restaurants: empirical evidence from China. International Journal of Quality \& Reliability Management, 27(4), 424-437. http://dx.doi.org/10.1108/02656711011035129

Schumacker, R. E., \& Lomax, R. G. (2004). A Beginner's Guide to Structural Equation Modeling (2nd ed.). London: Lawrence Erlbaum Associates.

Selnes, F. (1993). An examination of the effect of product performance on brand reputation, satisfaction and loyalty. European Journal of Marketing, 27(9), 19-35. http://dx.doi.org/10.1108/03090569310043179

Sharma, N., \& Patterson, P. G. (1999). The impact of communication effectiveness and service quality on relationship commitment in consumer, professional services. Journal of Services Marketing, 13(7), 151-170. http://dx.doi.org/10.1108/08876049910266059

Shiang-Lin, M. C., Jang S. C., \& Hu, C. (2005). Service quality gap analysis toward customer loyalty: practical guidelines for casino hotels. International Journal of Hospitality Managemen, 24, 465-472. http://dx.doi.org/10.1016/j.ijhm.2004.09.005

Soderlund, M. (1998). Customer satisfaction and its consequences on customer behaviour revisited. International Journal of Services Industry Management, 9(2), 169-188. http://dx.doi.org/10.1108/09564239810210532

Sudhahar, J. C., Israel, D., Prabhu, B. A., \& Selvam, M. (2006). Service Loyalty Measurement Scale: A Reliability Assessment. American Journal of Applied Sciences, 3(4), 1814-1818. http://dx.doi.org/10.3844/ajassp.2006.1814.1818

Torres, A., \& Tribó, J. A. (2010). Customer satisfaction and brand equity. Journal of Business Research, 64(10), 1089-1096. http://dx.doi.org/10.1016/j.jbusres.2010.12.001

Webster, C. \& Sundaram, D. S. (1998). Service consumption criticality in failure recovery. Journal of Business Research, 41(2), 153-159. http://dx.doi.org/10.1016/S0148-2963(97)00004-0

Wei, Z. (2004). Study on the Degree of Hotel's s Customer Satisfaction. (Master's thesis). Department of Forestry and Technology college of Tourism of Central South University.

Williams, P., \& Naumann, E. (2011). Customer satisfaction and business performance: a firm-level analysis. Journal of Services Marketing, (25/1), 20-32. http://dx.doi.org/10.1108/08876041111107032

Yi-Ting, Y., \& Dean, A. (2001). The contribution of emotional satisfaction to consumer loyalty. International Journal of Service Industry Management, 12(3), 234-250. http://dx.doi.org/10.1108/09564230110393239

Zeithaml, V. A. (1988). Consumer perceptions of price, quality, and value: a means-end model and synthesis of the evidence. Journal of Marketing, 52(3), 2-22. http://dx.doi.org/10.2307/1251446

Zeithaml, V. A., Berry, L. L., \& Parasuraman, A. (1996). The behavioral consequences of service quality. Journal of Marketing, 60(2), 31-46. http://dx.doi.org/10.2307/1251929

Zins, A. H. (2001). Relative attitudes and commitment in customer loyalty models: Some experiences in the commercial airline industry. International Journal of Service Industry Management, 12(3/4), 269-294. http://dx.doi.org/10.1108/EUM0000000005521 
Table 1. The tourism revenue of Yunnan province, 2009 (unit 100 million yuan)

\begin{tabular}{llll}
\hline Region & Total Tourism Revenue & Region & Total Tourism Revenue \\
\hline Kunming & 226.34 & Yuxi & 33.94 \\
Dali & 92.26 & Wenshan & 30.40 \\
Lijiang & 88.66 & Baoshan & 24.07 \\
Jinghong & 62.36 & Chuxiong & 21.58 \\
Honghe & 57.96 & Zhaotong & 14.98 \\
Diqing & 49.84 & Pu'er & 13.44 \\
Qujing & 38.69 & Lincang & 10.99 \\
Dehong & 38.53 & Nujiang & 6.64 \\
Total & 810.73 & & \\
\hline
\end{tabular}

Table 2. The variable, dimensions, measurement of this research

\begin{tabular}{|c|c|c|c|}
\hline Variables & Items & Cronbach's $\alpha$ & Source \\
\hline \multicolumn{4}{|l|}{ Service Quality } \\
\hline \multicolumn{4}{|l|}{ Functional Quality } \\
\hline \multirow[t]{5}{*}{ Tangibles } & 1. The hotels have modern looking equipment. & 0.833 & Parasuraman et al., \\
\hline & 2. The physical facilities at the hotel are visually appealing. & & Chengwei, \\
\hline & 3. Staff at the hotel appear neat (uniform, grooming). & & 2010 \\
\hline & 4. The good guide book, say to read and effectively. & & \\
\hline & 5. When the hotel promised to do something by a certain time. & & \\
\hline \multirow[t]{4}{*}{ Reliability } & $\begin{array}{l}\text { 1. When patrons have problems, the hotel shows a genuine interest } \\
\text { in solving them? }\end{array}$ & 0.740 & \\
\hline & 2. The hotel performs the service right the first time. & & \\
\hline & 3. The hotel provides its services at the time it promises to do so. & & \\
\hline & 4. The hotel insists on error-free service. & & \\
\hline \multirow[t]{4}{*}{ Responsiveness } & $\begin{array}{l}\text { 1. Staff at the hotel was able to tell patrons exactlywhen services } \\
\text { would be performed. }\end{array}$ & 0.835 & \\
\hline & 2. Staff at the hotel gives prompt service to thepatrons. & & \\
\hline & 3. Staffs at the hotel are always willing to help patrons. & & \\
\hline & 4. Staffs of the hotel are never too busy to respond to patrons. & & \\
\hline \multirow[t]{4}{*}{ Assurance } & 1. The behavior of staff instills confidence in its patrons. & 0.742 & \\
\hline & 2. Patrons of the hotel feel safe in their transactions. & & \\
\hline & 3. Staffs of the hotel are consistently courteous with patrons. & & \\
\hline & 4. Staff of the hotel has the knowledge to answer patrons. & & \\
\hline \multirow[t]{5}{*}{ Empathy } & 1. The hotel gives patrons individualized attention. & 0.840 & \\
\hline & 2. The hotel has opening hours convenient to all of its patrons. & & \\
\hline & 3. The hotel has staff who give its patrons personalized attention. & & \\
\hline & 4. The hotel has the patrons' best interests at heart. & & \\
\hline & $\begin{array}{l}\text { 5. The staff of the hotel understands the specific needs of their } \\
\text { patrons. }\end{array}$ & & \\
\hline \multirow[t]{4}{*}{ Technical Quality } & $\begin{array}{l}\text { 1. The employee offering the complete service what I asked and } \\
\text { no miss. }\end{array}$ & 0.725 & $\begin{array}{l}\text { Bell et al., 2005; } \\
\text { Brady and Cronin, }\end{array}$ \\
\hline & 2. The employee has the knowledge to answer my question. & & 200); Sharma and \\
\hline & $\begin{array}{l}\text { 3. Employee knows what they are talking about and has } \\
\text { responsibility handle to what they said. }\end{array}$ & & $\begin{array}{l}\text { Patterson, 1999; Ng } \\
\text { et al., } 2011\end{array}$ \\
\hline & $\begin{array}{l}\text { 4. Through employees' working behavior, I recognized he/she is } \\
\text { tasks competently. }\end{array}$ & & \\
\hline
\end{tabular}


Table 2. (Continued)

\begin{tabular}{|c|c|c|c|}
\hline Variables & Items & bach's $\alpha$ & Source \\
\hline \multicolumn{4}{|l|}{ Customer Loyalty } \\
\hline Word of Mouth & $\begin{array}{l}\text { 1. I will say positive things about the hotel to other people. } \\
\text { 2. I will speak well about this hotel service to other people. } \\
\text { 3. I will recommend the hotel if someone ask for my advice. } \\
\text { 4. I will encourage my friend or relations to visit this hotel. }\end{array}$ & 0.811 & $\begin{array}{l}\text { Parasuraman et } \\
\text { al., 2005; } \mathrm{Ng} \text { et } \\
\text { al., } 2011\end{array}$ \\
\hline Re-Patronage & $\begin{array}{l}\text { 1. I am looking forward to returning this hotel. } \\
\text { 2. I am likely to come back to this hotel. } \\
\text { 3. My intention is to re-booking with this hotel in the future. } \\
\text { 4. I don't care about your price is than other hotels cause I like your hotel. }\end{array}$ & 0.803 & $\begin{array}{l}\text { Bigné et al., 2001; } \\
\text { Zeithaml et al., } \\
\text { 1996; Loureiro } \\
\text { and Kastenholz, } \\
2010\end{array}$ \\
\hline Trust & $\begin{array}{l}\text { 1. This hotel is like a friend to me. } \\
\text { 2. The hotel employees go out of way for me. } \\
\text { 3. The people in the hotel respond caringly when I share my problems. } \\
\text { 4. The hotel employees are filled with professionalism and dedication. }\end{array}$ & 0.840 & $\begin{array}{l}\text { Moorman et al., } \\
\text { 1992; Sudhahar et } \\
\text { al., } 2006\end{array}$ \\
\hline Complaining & $\begin{array}{l}\text { 1. Switch to a competitor if you experience a problem with hotel's } \\
\text { service. } \\
\text { 2. Complain to other consumers if you experience a problem with hotel's } \\
\text { service. } \\
\text { 3. Complain to external agencies, such as the Better Business Bureau, if } \\
\text { you experience.ba problem with hotel's service. } \\
\text { 4. Complain to hotel's employees if you experience a problem with } \\
\text { hotel's service. }\end{array}$ & 0.732 & $\begin{array}{l}\text { Bloemer et al., } \\
\text { 1999, Zeithaml et } \\
\text { al., } 1996\end{array}$ \\
\hline \multicolumn{4}{|c|}{ Customer Satisfaction } \\
\hline & $\begin{array}{l}\text { 1. Would you agree to say "I am satisfied with my decision to visit this } \\
\text { hotel". } \\
\text { 2. Would you agree to say "My choice to stay at this hotel was a wise } \\
\text { one". } \\
\text { 3. Would you agree to say "I think I did the right thing when I chose to } \\
\text { stay in this hotel". } \\
\text { 4. Would you agree to say "I feel that my experience with this hotel/motel } \\
\text { has been enjoyable"? }\end{array}$ & 0.860 & $\begin{array}{l}\text { Olorunniwo \& } \\
\text { Hsu, 2006; Qin et } \\
\text { al., } 2010\end{array}$ \\
\hline \multicolumn{4}{|l|}{ Brand Image } \\
\hline & $\begin{array}{l}\text { 1. The hotel is comfortable. } \\
\text { 2. The hotel has a very clean image. } \\
\text { 3. The hotel is a suitable place for high class. } \\
\text { 4. I become special by visiting this hotel. } \\
\text { 5. The hotel's staff is very kind. } \\
\text { 6. The hotel has a differentiated image from other hotel brands. }\end{array}$ & 0.903 & $\begin{array}{l}\text { Keller and } \\
\text { Lehman, 2006; } \\
\text { Kayaman and } \\
\text { HuseyinArasli, } \\
2007\end{array}$ \\
\hline
\end{tabular}

Table 3. Return rate of questionnaires

\begin{tabular}{llll}
\hline Target City & Sent & Return & Response Rate \\
\hline Kunming City & 200 & 114 & $57.0 \%$ \\
Dali City & 200 & 108 & $54.0 \%$ \\
Lijiang City & 200 & 105 & $52.5 \%$ \\
Jinghong City & 200 & 85 & $42.5 \%$ \\
Total City & 800 & 412 & $51.5 \%$ \\
\hline
\end{tabular}


Table 4. The fit indices and analysis result of the research model

\begin{tabular}{lll}
\hline Fit indices & Recommended value & Result \\
\hline Chi-square/df & $<2.0$ & 1.15 \\
RMSEA & $<0.05$ & 0.02 \\
GFI & $>0.9$ & 0.97 \\
RMR & $<0.05$ & 0.01 \\
NFI & $>0.9$ & 1.00 \\
NNFI & $>0.9$ & 1.00 \\
CFI & $>0.9$ & 1.00 \\
\hline
\end{tabular}

Table 5. The path analysis

\begin{tabular}{lllll}
\hline \multirow{2}{*}{ Independent variable } & \multicolumn{3}{c}{ Dependent variable } \\
\cline { 2 - 5 } SQ & Effect & CS & CL & BI \\
& DE & $0.91^{* * *}$ & $0.70^{* * *}$ & -0.17 \\
& IE & -- & 0.27 & 1.11 \\
CS & TE & $0.91^{* * *}$ & $0.97^{* * *}$ & 0.94 \\
& DE & & $0.30^{* * *}$ & $0.44^{* * *}$ \\
& IE & & -- & 0.22 \\
CL & TE & & $0.30^{* * *}$ & $0.66^{* * *}$ \\
& DE & & $0.75^{* * *}$ \\
\hline
\end{tabular}

Note: $\mathrm{DE}=$ Direct Effect, IE=Indirect Effect, $\mathrm{TE}=$ Total Effect. ${ }^{*} \mathrm{P}<0.10,{ }^{* *} \mathrm{P}<0.05,{ }^{* * *} \mathrm{P}<0.01$.

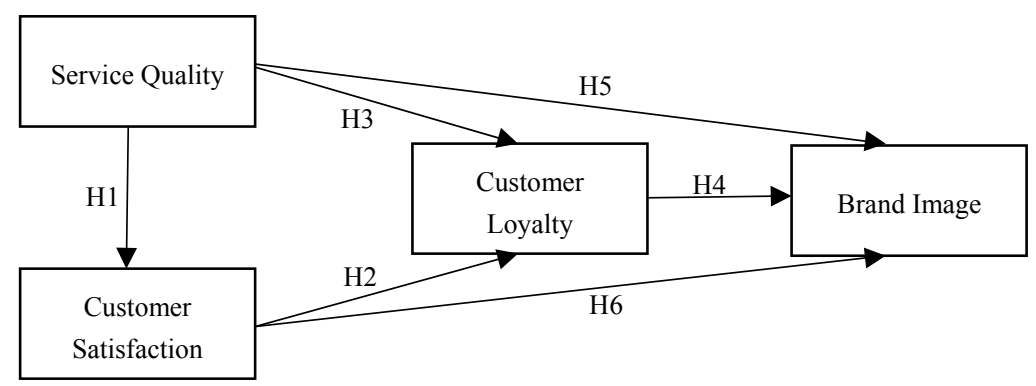

Figure 1. Framework/The brief model 


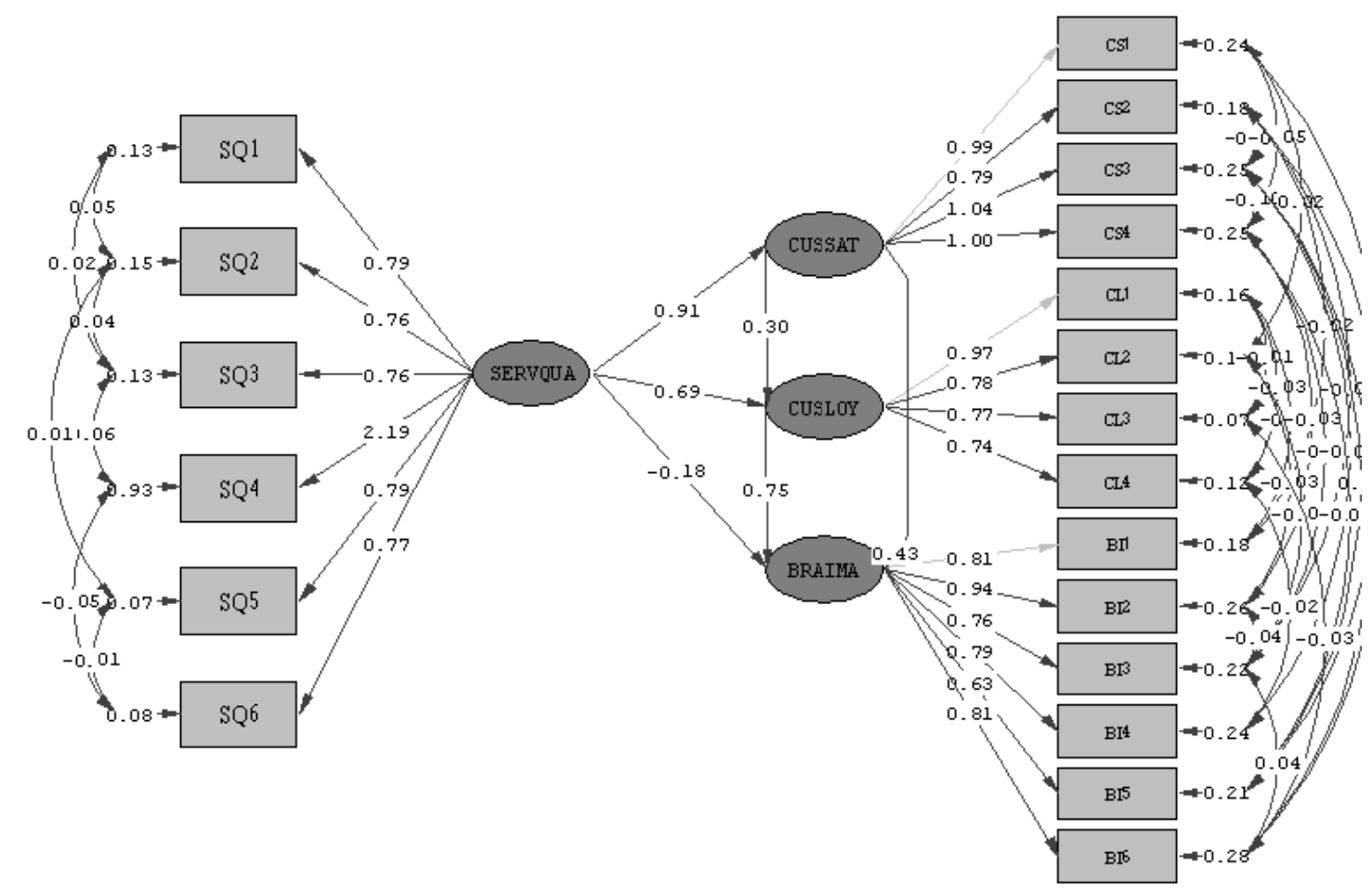

Chi-Square=148.78, df=129, P-value=0.11226, RMSEA $=0.019$

Figure 2. The research model $(n=412)$

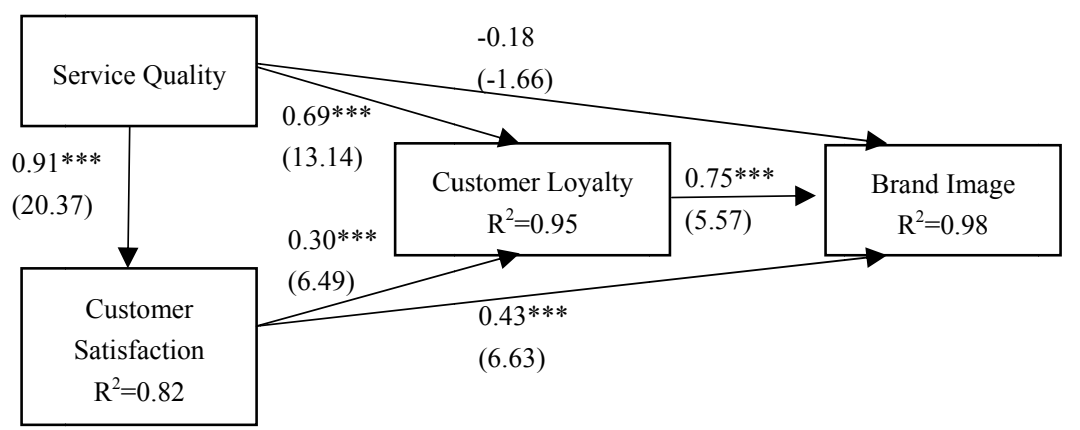

Figure 3. The brief result

Note: $* * * \mathrm{P}<0.01$ indicates the path relationship is significant value within the parenthesis is $\mathrm{T}$-Value.

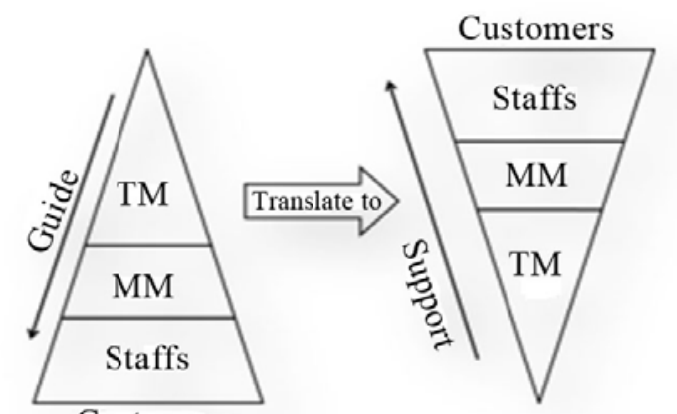

Customers

Figure 4. Different hotel's structural pyramid 